\title{
Factors Influencing Satisfaction on E-Banking
}

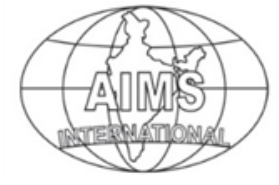

DOI: $10.26573 / 2017.11 .2 .2$

\author{
S. Kavitha \\ GRG School of Management Studies \\ Coimbatore, India \\ (kavitha@grgsms.ac.in)
}

Volume 11, Number 2

May 2017, pp. 103-115

Information technology has made enormous changes in to the way in which the business enterprises operate today. This is very much true for service industries like banks which experienced tremendous change in their business process. On the other side, due to LPG (Liberalization, Privatization and Globalization) era, customers especially bank customers have become more demanding and choosy. In this competitive world, the success of business will be based on how effectively they utilize the information technology tools for satisfying the needs of the customers at the right time, right place and at the right cost. There are number of delivery channels available in the banking industry to reach the customers. The widely used technologies like ATM, Internet Banking, Mobile Banking, SMS banking etc are satisfying the needs of the customers. But the effectiveness of usage of these tools decides the success of the functioning of banks. This research was an attempt to identify customer satisfaction on the e-banking services offered by banks with special reference to online banking. This was assessed with the help of five dimensions (Security, Performance, Training, Reliability and Ease of use) identified through various review of literature. A questionnaire was constructed and circulated and finally 250 questionnaires with complete responses were included in the study to identify their satisfaction about e-banking services provided by the banks in Tamil Nadu. The data collected were analyzed using the statistical tools like Multiple Regression, Chi Square and Simple Percentage analysis. Based on the results, suggestions were given to bankers for offering the best e-banking services to their customers.

Keywords: E-Banking, Customer Satisfaction, Ease of use, Training and Performance, Security, Reliability

\section{Introduction}

In this era of intense competition, only the companies which understand the needs of the customers and satisfy the needs alone can survive. Customers are important assets for any business. Companies should adopt right strategies to satisfy the needs of their customers. This process has become very easy in today's environment because of the enormous growth of information technology tools that can be used in business for satisfying the needs of customers at the faster rate. Service industries especially the banks are taking lot of initiatives to make the best use of information technology tools and techniques. There has been an increase of competition in the banking industry that made other banks try to develop different approaches to electronic banking. In order to remain competitive in the market and for having a 
larger share in the market a company needs to have loyal customer base. These important issue prerequisites cannot be achieved except by earning their trust. (Akbari et.al. 2012). So high level of customer satisfaction will be essential for the sustainability of banks and this could be achieved when the customer satisfaction by new upgraded services is measured and also the type of banking service that is able to attract customers more than the other competes is recognized. Factors that influence on adoption of various technologies and information technology are different depending on the desired technology of studied users and the existing situation. Customer satisfaction towards internet banking service has become an issue due to stiff competition among the banks in India. Customer satisfaction is critically important for its impact on customer retention and firm profitability. Internet banking service quality and customer satisfaction are inarguably the two core concepts for the researchers. It has been identified through various researches that quality of internet banking service is a key issue to maintain customer satisfaction. (Sharma et al., 2014). Even though many studies have been conducted to identify the customer satisfaction on e-banking, Tamil Nadu level study to analyze the customer satisfaction on e-banking with the widely adopted dimensions, will help the bankers to formulate strategies for improving their quality of services on ebanking.

\section{Theoretical Background}

E-banking or Internet Banking or online banking is a convenient way to do banking from the comfort of any one's home or office. According to Oxford Dictionary ebanking is a method of banking in which the customer conducts transactions electronically via the Internet. (Source: http:// www.oxforddictionaries.com /definition /English/e-banking). Users need not wait in a long queue in front of counters rather can do all the transactions from their convenient place. According to Daniel (1999), electronic banking is the delivery of banks ' information and services by banks to customers via different delivery platforms that can be used with different terminal devices such as personal computer and mobile phone with browser or desktop software, telephone or digital television. Electronic banking, therefore, could be categorized into PC banking, Internet banking, TV-based banking, and Telephone based banking. The SBI Retail Internet Banking offers a plethora of products and services, to cater to all the banking demands of the customers like Transfer funds to own and third party accounts, A suite of completely online deposit products (Fixed, Recurring, Flexi, Tax Saving etc.), Airline, Rail, Bus and hotel ticket booking, Online Shopping and instant recharge features, IMPS Funds Transfer, Western Union Service, Credit beneficiary accounts using RTGS/NEFT feature, Generate account statements, scheduling payments, Configure profile settings, E- Tax for online tax payment, E - Pay for automatic bill payments etc., The Corporate Internet Banking (CINB) facility of SBI enables the corporate customer to carry out banking activities anywhere and anytime aided with the power and convenience of the internet. According to ICICI web site, Internet Banking is a convenient way to do banking from the comfort of the customers' home or office. They can avoid the queue or delays by trying their simple and secure Internet Banking facility for an unmatched online banking experience. To experience the internet banking customers have to just login using their user id and password. 
Customer Satisfaction (CS) has become a major area of marketing that has received considerable publications from practitioners and scholars in the last two decades. According to Kotler (2016), satisfaction reflects a person's judgment of a product's perceived performance in relationship to expectations. If performance falls short of expectations, the customer is disappointed. If it matches customer expectations, they are satisfied and if it exceeds them the customer is delighted. In short satisfaction is a person's feeling of pleasure or disappointment resulting from comparing a product's performance (outcome) in relation to his or her expectation. Customer satisfaction can be defined as the overall customer evaluation of a product or service based on purchase and consumption experience over a time period. The quality of services provided by the bankers in the banking sector plays important role in the satisfaction of customer. The increase in customer satisfaction level leads to decrease in operating and service costs. This provides an opportunity for banks to expand their product portfolio and services for the future development. (Sanyal, 2016). Different researchers have attempted to measure the customer satisfaction on e-banking services using different dimensions like Safety, Reliability, Transactions efficiency, Customer support, Service Security, Ease of use, Performance, Accuracy, Timeliness, Confidence, Content, Format, Responsiveness etc.

\section{Literature Review}

The customer user satisfaction concept was applied in the area of information systems in the early 1980s. Different authors have studied the concept of customer satisfaction on e-banking using different dimensions. Bailey and Pearson (1983) have developed a measuring instrument to analyze computer user satisfaction. This instrument was adopted by researchers and practitioners for high validity and reliability. They also have identified 38 factors affecting user satisfaction and developed a questionnaire using 7-point semantic differential scale of adjective pairs. Later Torkzadeh and Doll (1988) have modified the instrument from previous studies and reduced the factors into five factors with 12 items. The final developed factors were, content, accuracy, format, ease of use and timeliness. In 1991 they used the term End User Computing Satisfaction as "the affective attitude towards a specific computer application by someone who interacts with the application directly". This means that the interaction could be towards any computer-based systems that has human-computer interaction.

In 2004 Pikkarainen model is proposed by Pikkarainen and colleagues which examines the factors that influence the Internet use of services or goods. The researchers announced six effective factors on Internet transactions of goods and services (usefulness, ease of use, Enjoyment, Providing information, security and confidentiality, Internet connection quality.) This model was designed and tested for acceptance of electronic banking and the model is derived from the Technology Acceptance Model. (Davis.F.D. 2000)

Salehi, Rostami, and Mogadam (2010) have studied computer user satisfaction to end user in AIS environment. They have used a modified version of Doll and Torkzadeh (1988) instrument and tested for its validity and reliability. This paper validates accuracy, ease of use, timeliness, content, format, system speed and system reliability. There were many attempts to simplify the factors and to suit it with studies related to computer user satisfaction. 
Kumphar (2011) conducted a study on demographic profile of customers and its relationship with perception of service quality, service value and overall satisfaction in e-banking. The study showed that demographic characteristics like age, education, profession and income level are influencing perceived service quality, perceived value and overall satisfaction in e-banking. So the author recommended the banks to adopt the right strategies as per the demographic profile of the customers.

Gupta and Bansal (2012) tried to develop an instrument for measuring Internet banking service quality in India and they also analyzed the impact of Internet banking service quality dimensions on the overall Internet Banking Service Quality (IBSQ) and customer satisfaction. They developed a service quality scale of 22 items. Using exploratory factor analysis they reduced the 22 items into five dimensions: Security/Privacy, Reliability, Efficiency, Responsiveness, and Site Aesthetics. Model was further validated through Confirmatory Factor Analysis. They carried out a survey among the Internet banking users of Private, Public and Foreign banks in Delhi. Multiple regression analysis revealed that security/Privacy dimension carries the maximum impact on the overall IBSQ whereas customer satisfaction is mostly affected by the Efficiency dimension as compared to other dimensions.

Rangsan Nochai and Titida (2013) conducted a survey to examine the impact of seven internet banking service quality dimensions on customer satisfaction using multinomial logistic regression analysis. A survey was done on customers of top three banks in the Bangkok who use Internet Banking. Results showed that Safety reliability, Transactions efficiency, Customer support, Service security, Ease of use and Performance have a significant impact on customer satisfaction.

Sharma \& Malviya (2014), conducted a study on Internet banking service quality and its impact on Customer Satisfaction in Indore district. They developed a model based on service quality dimensions like ease of use, comfort, accessibility, confidence and responsiveness with the purpose to investigate the impact of service quality on customer satisfaction. Through multiple regression analysis they concluded that all five dimensions were having impact on customer satisfaction. Ease of use, comfort and accessibility were the most important dimensions which influence the customer satisfaction on e-banking.

Table 1 Summary of Different Studies on E-Banking over Different Period and Factors as EBanking Service Dimensions

\begin{tabular}{|l|c|l|}
\hline Author & Year & \multicolumn{1}{|c|}{ Factors/Dimensions } \\
\hline $\begin{array}{l}\text { Bailey \& } \\
\text { Pearson }\end{array}$ & 1983 & $\begin{array}{l}\text { Accuracy, Reliability, Timeliness, Relevancy, Confidence in the } \\
\text { system (like that 38 factors) }\end{array}$ \\
\hline $\begin{array}{l}\text { Torkzadeh \& } \\
\text { Doll }\end{array}$ & 1988 & $\begin{array}{l}\text { Content, Accuracy, Format, Ease of Use and } \\
\text { Timeliness }\end{array}$ \\
\hline $\begin{array}{l}\text { Pikkarainen } \\
\text { Model }\end{array}$ & 2004 & $\begin{array}{l}\text { Usefulness, Ease of use, Enjoyment, Providing information, Security, } \\
\text { Confidentiality and Internet Connection quality }\end{array}$ \\
\hline $\begin{array}{l}\text { Salehi, Rostami, } \\
\text { Mogadam }\end{array}$ & 2010 & $\begin{array}{l}\text { Accuracy, Ease of use, Timeliness, Content, Format, System speed } \\
\text { and reliability }\end{array}$ \\
\hline Gupta \& Banzal & 2012 & $\begin{array}{l}\text { Security/Privacy, Reliability, Efficiency, Responsiveness, Site } \\
\text { Aesthetics }\end{array}$ \\
\hline $\begin{array}{l}\text { Rangsan. Nochai } \\
\text { and Titida }\end{array}$ & 2013 & $\begin{array}{l}\text { Safety, Reliability, Transactions efficiency, Customer support, Service } \\
\text { Security, Ease of use and Performance }\end{array}$ \\
\hline $\begin{array}{l}\text { Sharma \& } \\
\text { Malviya }\end{array}$ & 2014 & Ease of Use, Responsiveness, Comfort, Accessibility, Confidence \\
\hline
\end{tabular}


Based on the above reviews, it was clear that different authors used different dimensions to test the customer satisfaction on e-banking. From the above reviews, the five dimensions namely Security, Performance, Training, Reliability and Ease of use were selected to assess the customer/user satisfaction on e-banking. The following study was conducted to identify the relationship between different dimensions of e-banking and the customer satisfaction on e-banking. The study also tried to identify the relationship between demographic profile of the respondents and customer satisfaction on e-banking. (Kumphar 2011).

\section{Objectives}

- To identify the relationship between e-banking dimensions and customer satisfaction on e-banking.

- To find the relationship between demographic profile of the respondents and customer satisfaction on e-banking.

The broad research question is

- What are the dimensions affecting the customer satisfaction on e-banking?

\section{Research Model Proposed for the Study}

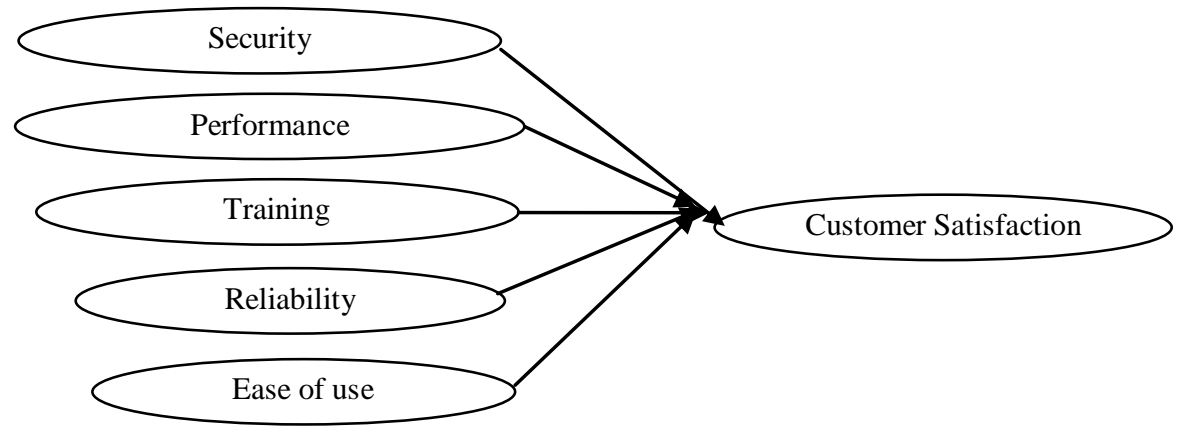

Figure 1 Relationship between Selected E-Banking Dimensions and Customer Satisfaction

Based on the framework, the proposed hypotheses are

H1: Security will have an impact on Customer Satisfaction on E-banking

H2: Performance will have an impact on Customer Satisfaction on E-Banking

H3: Training will have an impact on Customer Satisfaction on E-Banking

H4: Reliability will have an impact on Customer satisfaction on e-banking

H5: Ease of use will have an impact on Customer Satisfaction on E-Banking

H6: Demographic profile of the respondents' will have an impact on customer satisfaction on e-banking.

\section{Methodology}

Descriptive research design was used for the study. Both primary and secondary data was collected. Structured questionnaire was used as a source of primary data and apart from this some relevant secondary information were obtained from news papers, magazines, records, websites and books. The population of the study was the bank customers in Tamilnadu who uses e-banking/internet banking services. 
A pilot study was done by administering questionnaire on 50 respondents selected at random. As per the pilot study, minor changes were made into the questionnaire before carrying out the final data collection. The questionnaire was divided into two parts. First part includes questions related to demographic profile of respondents and second part includes the respondents' opinion on e-banking in the service quality dimensions like Security, Performance, Training, Reliability and Ease of use.. The respondents have given their opinion in a five point Likert Scale (5-Strongly Agree, 4-Agree, 3 - Neutral, 2 - Disagree, 1 - Strongly Disagree). The population for the study was list of bank customers who use e-banking facilities in Tamilnadu. The study was undertaken among both public and private sector bank customers, who use internet banking facility. Data was collected from Individual customers of the public and private sector banks who use internet banking services by logging into the banks online banking website using the Use rid and password provided to them by the bank using a desktop or a laptop. Samples were selected using non probability Snow-Ball sampling. 250 complete questionnaires collected from the respondents were included for analysis. The data collection was done during Nov 2013 - Mar 2014. Cronbach's Alpha Test of Reliability is applied to test whether the items pertaining to scale, each items were internally consistent and whether they can be used to measure the proposed phenomena e.g. e-Banking dimensions like Security, Performance, Training, Reliability and Ease of use. All the values were found to be more than 0.8 . The data analysis like Simple percentage analysis, Multiple Regression and Chisquare analysis were carried out using SPSS. The demographic profile of the respondents was analyzed using simple percentage analysis. The hypotheses related to the impact of e-banking five dimensions selected for the study like Security, Performance, Training, Reliability and Ease of use on Customer Satisfaction was tested using Multiple Regression Analysis. The relationship between demographic profile of the respondents and Customer Satisfaction was tested using Chi-square analysis. The results of the analysis were tabulated and interpreted as shown below.

\subsection{Simple Percentage Analysis}

\section{Analysis and Discussion}

The respondents were asked about their demographic details like age, gender, education, computer knowledge, occupation, income and period of relationship with the banks. The distribution of respondents on the basis of demographic profile was tabulated below.

\subsection{Multiple Regression}

A regression is a statistical tool used to find out the relationship between two or more variables. In simple regression, there will be only two variables; one variable is caused by the behavior of other variable. The variable, which is causing the behavior of other variable, is called independent variable, and the variable which is caused by other variable, is called dependent variable. When there are two or more independent variables, which affect the behavior of one dependent variable such relationship is called multiple regression or linear regression. Linear regression estimates the coefficients of the linear equation, involving one or more independent variables that best predict the value of dependent variable. 
H1 - H5: Security, Performance, Training, Reliability and Ease of use will have an impact on customer satisfaction on e-banking.

Table 2 Demographic Profile of the Respondents

\begin{tabular}{|c|c|c|c|c|}
\hline S No & Demographic variable & Group & $\begin{array}{c}\text { No. of } \\
\text { Respondents }\end{array}$ & $\begin{array}{c}\text { Percentage of } \\
\text { respondents }\end{array}$ \\
\hline \multirow{5}{*}{1} & \multirow{5}{*}{ Age(years) } & $<20$ & 15 & 6.0 \\
\hline & & $20-35$ & 136 & 54.4 \\
\hline & & $36-50$ & 59 & 23.6 \\
\hline & & $51-65$ & 30 & 12.0 \\
\hline & & above 65 & 10 & 4.0 \\
\hline \multirow{2}{*}{2} & \multirow{2}{*}{ Gender } & Male & 165 & 66.0 \\
\hline & & Female & 85 & 34.0 \\
\hline \multirow{4}{*}{3} & \multirow{4}{*}{ Education } & Higher secondary & 10 & 4.0 \\
\hline & & Graduation & 50 & 20.0 \\
\hline & & Post Graduation & 101 & 40.4 \\
\hline & & Professional & 89 & 35.6 \\
\hline \multirow{5}{*}{4} & \multirow{5}{*}{ Computer Knowledge } & Zero & 45 & 18.0 \\
\hline & & Basic & 41 & 16.4 \\
\hline & & Diploma & 96 & 38.4 \\
\hline & & Graduate & 18 & 7.2 \\
\hline & & Post Graduate & 50 & 20.0 \\
\hline \multirow{5}{*}{5} & \multirow{5}{*}{ Occupation } & $\begin{array}{c}\text { Government } \\
\text { Employee }\end{array}$ & 50 & 20.0 \\
\hline & & Private Employee & 129 & 51.6 \\
\hline & & Business & 28 & 11.2 \\
\hline & & Profession & 29 & 11.6 \\
\hline & & Student & 14 & 5.6 \\
\hline \multirow{6}{*}{6} & \multirow{6}{*}{ Income } & 0 & 10 & 4.0 \\
\hline & & Below or $=10000$ & 33 & 13.2 \\
\hline & & $10,001-20,000$ & 54 & 21.6 \\
\hline & & $20,001-30,000$ & 118 & 47.2 \\
\hline & & $30,001-40,000$ & 10 & 4.0 \\
\hline & & $>40,000$ & 25 & 10.0 \\
\hline \multirow{4}{*}{7} & \multirow{4}{*}{$\begin{array}{c}\text { Period of relationship with } \\
\text { the bank }\end{array}$} & less than 1 year & 36 & 14.4 \\
\hline & & $1-3$ years & 71 & 28.4 \\
\hline & & 4-6 years & 37 & 14.8 \\
\hline & & $>6$ years & 106 & 42.4 \\
\hline
\end{tabular}

Source: Questionnaire

Model: Here customer satisfaction was taken as the dependent variable and the five dimensions of e-banking were the independent variables. The OLS Regression model was used to determine the significance level of the variables for the customer satisfaction on e-banking.

The basic model was as follows. 
Customer Satisfaction on e-banking $=\alpha+\beta 1 *$ Security $+\beta 2 *$ Performance $+\beta 3 *$ Training $+\beta 4 *$ Reliability $+\beta 5 *$ Ease of use

There $\alpha$ is constant and $\beta \mathrm{s}$ are coefficients to estimate, and e is the error term. The overall regression model and its ANOVA were summarized as follows

Table 3 Regression Model Summary

\begin{tabular}{|c|c|c|c|c|}
\hline Model & R & R Square & Adjusted R Square & Std. Error of the Estimate \\
\hline 1 & $.716^{\mathrm{a}}$ & .513 & .503 & 2.64651 \\
\hline
\end{tabular}

a. Predictors: (Constant), Reliability, Training, Security, Performance, Ease of use

Table 4 Anova

\begin{tabular}{|c|l|c|c|c|c|c|}
\hline Model & & Sum of Squares & Df & Mean Square & F & Sig. \\
\hline \multirow{3}{*}{1} & Regression & 1797.500 & 5 & 359.500 & 51.328 & $.000^{\mathrm{a}}$ \\
\cline { 2 - 8 } & Residual & 1708.984 & 244 & 7.004 & & \\
\cline { 2 - 8 } & Total & 3506.484 & 249 & & & \\
\hline
\end{tabular}

a. Predictors: (Constant), Reliability, Training, Security, Performance, Ease of use b. Dependent Variable: Level of Satisfaction

The ANOVA Test shows the p value - 0.000 which was less than 0.05 , hence the result was significant at $5 \%$ level of significance. It means there was a significant correlation between dependent variable and independent variables. Therefore, customer satisfaction level depends on different dimensions like Security, Performance, Training, Reliability and Ease of use. The overall predictability of the model was shown in the Model summary above. The adjusted R square value of .503 indicates that the model explains roughly about $50.3 \%$ of the variability in the dependent variable customer satisfaction on e-banking by the independent variables Security, Performance, Training, Reliability and Ease of use. The remaining 49.7 percent of the variation in customer satisfaction may be due to reasons not related to e-banking dimensions considered in the model.

Table 5 Coefficients

\begin{tabular}{|c|l|c|c|c|c|c|}
\hline Model & & Unstandardized Coefficients & Standardized Coefficients & T & Sig. \\
\hline \multirow{3}{*}{1} & & B & Std. Error & Beta & & \\
\hline \multirow{7}{*}{1} & (Constant) & 6.071 & 1.713 & & 3.543 & .000 \\
\cline { 2 - 8 } & Security & .221 & .042 & .321 & 5.290 & .000 \\
\cline { 2 - 8 } & Performance & .106 & .036 & .160 & 2.923 & .004 \\
\cline { 2 - 8 } & Training & .187 & .045 & .210 & 4.172 & .000 \\
\cline { 2 - 8 } & Reliability & .156 & .063 & .166 & 2.472 & .014 \\
\cline { 2 - 8 } & Ease of use & .713 & .105 & .361 & 6.786 & .000 \\
\hline
\end{tabular}

a Dependent Variable: Level of Satisfaction

Table 4 depicts significant $\mathrm{F}$ values which implies that the model and data were well fit in explaining customer satisfaction in e-banking. Based on the data found in 
the above Table, it could be interpreted that the independent variables such as Security, Performance, Training, Reliability and Ease of use have strong impact on customer satisfaction. The strongest relationship was between Ease of use and satisfaction followed by Security and satisfaction and Training and satisfaction.

The following Table shows the results of hypothesis testing.

Table 6 Results of Hypothesis Testing

\begin{tabular}{|c|l|c|c|c|l|}
\hline Hypothesis & Independent to Dependent Factor & Beta & F & $\begin{array}{c}\text { P- } \\
\text { Value }\end{array}$ & Result \\
\hline H1 & Security and Satisfaction & .221 & 5.290 & .000 & Hypothesis 1 Supported \\
\hline H2 & Performance and satisfaction & .106 & 2.923 & .004 & Hypothesis 2 Supported \\
\hline H3 & Training and satisfaction & .187 & 4.172 & .000 & Hypothesis 3 Supported \\
\hline H4 & Reliability and satisfaction & .156 & 2.472 & .014 & Hypothesis 4 Supported \\
\hline H5 & Ease of use and satisfaction & .713 & 6.786 & .000 & Hypothesis 5 Supported \\
\hline
\end{tabular}

From the above findings the following regression model was formed: Customer satisfaction on e-banking $=6.071+0.221^{*}$ Security $+0.106 *$ Performance $+0.187 *$ Training $+0.156 *$ Reliability $+0.713 *$ Ease of Use

From the above model it could be inferred that Ease of use was the dimension which brings about major change in the customer satisfaction on e-banking followed by Security and Training. The last two dimensions were Reliability and Performance. Ease of use was the very important dimension which affects the satisfaction of customers on e-banking. This result holds well with the results of different authors (Torkzadeh and Doll, 1988; Pikkarainen, 2004; Salehi, Rostami, Mogadam, 2010; Rangsan. Nochai and Titida, 2013; Sharma \& Malviya, 2014). Other dimensions like Security (Gupta and Banzal, 2012; Rangsan. Nochai and Titida ,2013), Performance (Rangsan. Nochai and Titida, 2013), Training (Rangsan. Nochai and Titida Customer Support , 2013) and Reliability (Gupta and Banzal, 2012; Rangsan. Nochai and Titida, 2013) also have some impact on the customer satisfaction on e-banking.

The study identified that ease of use was very important e-banking dimension that affect the customer satisfaction followed by security. So suggestion was given to the banks that e-banking working should be made easy without compromising on security at any cost since that was the second important dimension that affect the customer satisfaction on e-banking. Suggested changes include explaining and enforcing strong passwords, using the same code for temporary and permanent identification, and using a consistent terminology throughout the user interface. (Morten et al., 2004). Banks should take necessary steps to offer the user friendly ebanking facilities with good security. They should do some research on identifying the best technology for combining Ease of use with Security.

\subsection{Chi-Square Analysis - Demographic Profile of the Respondents and Level of Satisfaction}

In order to assess the relationship between the demographic profile of the respondents like age, gender, education, computer knowledge, occupation, income and period of relationship with banks and the level of satisfaction of customers on ebanking a hypotheses was framed and tested using chi-square analysis. 
H6: Demographic profile of the respondents will have an impact on customer satisfaction on e-banking.

Table 7 Results of Chi-Square Analysis - Demographic Profile and Level of Satisfaction

\begin{tabular}{|c|l|c|c|l|}
\hline S No & \multicolumn{1}{|c|}{ Demographic Variable } & Chi-Square Value & P value & \multicolumn{1}{|c|}{ Result } \\
\hline 1 & Age & 39.704 & .000 & Significant \\
\hline 2 & Gender & 12.38 & .060 & Not Significant \\
\hline 3 & Educational Qualification & 14.570 & .024 & Significant \\
\hline 4 & Computer Knowledge & 63.340 & .000 & Significant \\
\hline 5 & Occupation & 51.180 & .000 & Significant \\
\hline 6 & Income & 38.162 & .000 & Significant \\
\hline 7 & Period of relationship with bank & 51.956 & .000 & Significant \\
\hline
\end{tabular}

From the above chi-square analysis it is implied that the demographic profile like Age, Educational qualification, Computer knowledge, Occupation, Income and Period of relationship with bank have a positive relationship with level of satisfaction of bank customers on e-banking but Gender was not having any relationship with level of satisfaction on e-Banking.

Hence it can be concluded that the demographic profile of respondents like age, educational qualification, computer knowledge, occupation, income and period of relationship with bank are having a relationship with customer satisfaction on ebanking where as gender is not having any relationship with the same.

Hence the banks should devise the right strategies to attract the different segment of customers with different age group, educational qualification, computer knowledge, occupation, income and period of relationship with bank. Normally, young customers expect more service from e-banking since they are familiar with all latest services. So, banks should enhance their services to their expectations at the same time expectations of the elder customers also should not be ignored. Highly educated people will have the skill to operate with banking technology than the people with low education. Banks should consider this while designing e-banking services. Naturally people with good computer knowledge will feel it easy to work with technology. The people in different professions and different income groups may have different needs and services from e-banking. Banks should develop their ebanking services according to the expectations of people in different occupation and income range. (Kumphar, 2011). In this study, period of relationship with banks also has an impact on customer satisfaction. The customers with long term relationship will definitely have good customer satisfaction. Banks can utilize the e-banking services to retain the customers for long period. Banks should try to improve the ebanking services to attract the differentiated group of customers on the basis of age, income, education, computer knowledge, occupation, period of relationship with bank. They should design the e-banking services based on the needs of the different segments of people.

\section{Conclusion and Limitations}

To compete in this competitive marketplace and to sustain the competitive advantage, each and every organization has to adapt to the latest technologies, should 
identify the modifications to the existing technology by conducting research. This research seeks to make an original contribution to knowledge by investigating the impact of five e-banking dimensions like Security, Performance, Training, Reliability and Ease of use on Customer Satisfaction on e-banking. To introduce the security in e-banking services, the banks can incorporate new technologies like encrypting and verification. The security issues can be moderated through improved authenticating process, protecting password, information about site security, giving absolute loss guarantee (if something goes wrong during transaction banks should correct the errors without much delay), providing accessible customer service (multiple channels like SMS, E-mail and Toll free numbers should be given for customers to file their complaints) and educating customers on features of e-banking. (Maryam, 2013). Most of the studies showed that if Ease of use and Security is high, customer satisfaction on e-banking will increase. This is proved in this study and this will also increase the loyalty of customers towards bank and it will create positive Word of Mouth (WOM) in the context of e-banking services. The e-banking dimensions and its impact on customer satisfaction identified through this study will allow bank managers and policy makers to direct their efforts and resources in most effective and efficient way through which bank business can increase in long run and new customers can be encouraged to adopt and use e-banking. The study revealed that demographic profile of the respondents like age, education, computer knowledge, occupation, income and period of relationship with the bank are having relationship with e-banking satisfaction. Hence banks should give importance to segmenting their customers and offering products as per the needs of the segments. Adoption of e-banking by most of the customers will reduce the operational cost involved in bank transaction which will in turn help the banks to boost their profits. So this study can be used by bankers in deciding their e-banking practices which will increase the customer satisfaction and loyalty of bank customers. Since the study was conducted in Tamilnadu, the findings of the study could not be generalized. The study did not make any comparison between the adoption and satisfaction of ebanking between the public and private sector banks. The focus of the study was only on internet banking and other e-banking services like ATM, Mobile Banking, SMS banking etc., were not included in the study. Further studies can be conducted focusing on above areas.

\section{References}

1. Bailey, J. E and S. W. Pearson, "Development of a Tool for Measuring and Analyzing Computer User Satisfaction,” Management Science, 29(5), 1983, 530.

2. Cooper R.Donald, Pamela S. Shindler, "Business Research Methods", 2003, Tata McGraw Hill Publications, New Delhi.

3. Daniel, E, "Provision of Electronic Banking in the U.K. and Ireland", II International Journal of Bank Marketing, Vol. 17, 1999, 211-232

4. Davis, F., 'Perceived usefulness, perceived ease of use, and user acceptance of information technology', Management Information Systems Quarterly, 13(3), 1989, 319-339.

5. Doll, W. J. and G. Torkzadeh, "The Measurement of End-User Computing Satisfaction”, MIS Quarterly, 12(2), 1998, 259-274. 
6. Gupta, K. K, and D. I. Bansal, "Development Of An Instrument To Measure Internet Banking Service Quality In India", International Refereed Research Journal, 3, 2(2). 2012, 11-25

7. Kotler. P and K. Keller, "Marketing Management", 2016, 15th Ed., Pearson Education Inc, Noida.

8. Kumbhar M. Vijay, "Customers demographic profile and Customer satisfaction in E-Banking services, A study of Indian Banks", International Journal for Business Strategy and Management, 1(1), 2011, downloaded from www.veloxian.com/ecj/ijbsm.

9. Manoj Kumar Ambashta, "Customer orientation - A pre - requisite for banks' success", The journal of Indian Institute of Bankers, January - March,1997, 21.

10. Marimuthu Malliga and Ishak Ismail, Service Quality in Higher Education: Comparing the Perceptions of Stakeholders1, AIMS International Journal of Management, 6(2), 2012, 87-100.

11. Maryam Sahrabi et al, "Critical success factors for the adoption of e-banking in Malaysia", International Arab Journal of e-technology, 3(2), 2013, 76-82, downloaded from http://www.iajet.org/iajet_files/vol.3/no.2

12. Morten Hertzum, Niels Jorgensen, Mie Norgaard, "Usable security and ebanking, ease of use vis- a- vis security" downloaded from http://akira.ruc.dk/ nielsj/research/ publications/eBanking-ozchi.pdf

13. Parasuraman, A., V.A. Zeithaml, and L.L. Berry, "SERVQUAL: A MultipleItem Scale for Measuring Consumer Perceptions of Service Quality". Journal of Retailing, 64, 1988, 12-40

14. Peyman Akbari, Reza Rostami and Akbar Veismoradi, "Study of Factors Influencing Customer's use of Electronic Banking Services by Using Pikkarainens Model (Case study: Eghtesad Novin Bank of Kermanshah, Iran)", International Research Journal of Applied and Basic Sciences. 3 (6), 2012, 1218-1224, Downloaded from http:// www. irjabs.com

15. Rajyalakshmi Nittala \& A. Vijaya Kameswari, "Internal Marketing for Customer Satisfaction in Retail Sector" AIMS International Journal of Management Volume3, Number 3, September2009, 207-220.

16. Rangsan, Nochai and Titida, "The impact of Internet banking service on customer satisfaction in Tailand: A Case study in Bangkok", International Journal of Humanities and Management Sciences, 1(1), (Online), 2013, 101105.

17. Salehi, Rostami, and Mogadam, "Usefulness of Accounting Information System in Emerging Economy: Empirical Evidence of Iran", International Journal of Economics and Finance, 2(2), 2013, 186-195.

18. Shainesh.G and Ramneesh Mohan, "The status of customer relationship in India, survey of service firms", Sheth N. Jagdish et.al., Customer relationship management - Emerging Concepts, Tools and Applications, Tata Mcgraw hill Publications, New Delhi, 2000, 369-378

19. Sharma Geetha, Surendra Malviya, "Internet Banking Service Quality and Its Impact On Customer Satisfaction In Indore District Of Madhya Pradesh", International Journal of Business and Management Invention, 3(3), 2014, 01-06, downloaded from www.ijbmi.org

20. Simon Gyasi Nimako, Nana Kwame Gyamfi, Abdil Mumuni Moro Wandaogou, Customer satisfaction with internet banking service quality in the Ghanaian 
banking industry, International Journal of Scientific \& Technology Research, volume 2, issue 7, July 2013

21. Shouvik Sanyal, Customer Satisfaction on E-Banking Services in Private and Public Sector Banks : A Comparative Analysis in Dhofar Region of Sultanate of Oman, International Journal of Economic Research · January 2016

22. Sundar, K. and Lakshmanan, "Customer Care Management in banks", Management Marketers, 1(3), September-February, 2005, 93-96

23. Upinder Dhar, Santosh Dhar and Abhinav Jain, "Service with a difference: A Comparative Analysis of Private and Public Sector Banks", Prestige Journal of Management and Research, 8(1 \& 2), April-October, 2004, 17-29

24. Uma Sekaran, "Research Methods for Business, A Skill Building approach", 2009, Wiley India, IVth edition, Noida.

25. Venkatesh.V, M.G.Morris and F.D Davis, "User Acceptance of Information Technology: Toward a Unified view”, MIS quarterly, 27, 2003, 425-478.

\section{Websites}

- $\quad$ https://retail.onlinesbi.com/personal/aboutus.html

- http://www.icicibank.com/Personal-Banking/insta-banking/internetbanking/index.page

\section{About Our Author}

S. Kavitha has about 13 years of teaching and 3 years of industry experience. Presently she is working as Associate Professor in GRG School of Management Studies, Coimbatore. Her education qualification includes, BSc CT, MBA, MCA, M. Phil., Ph.D. She is a gold medalist in both MBA and MCA. She cleared UGC-NET in Management in 2006. She is the recipient of All India Management Association certificate "Accredited Management Teacher" in the Information technology domain. She has 15 International Publications, 4 National publications and 6 ISBN edited publications in referred journals. She acted as a resource person for the workshops on "Application of SPSS in Management Research" organized by Vedha Vyasa College of Technology, Calicut and Erode Sengunthar Engineering College. She acted as a Resource Person for a session in the ICSSR-sponsored two-week "Capacity Building Workshop" for social science faculty organised by PRIMS, Periyar University. She organized MDP and acted as a resource person for FDPs organized by GRGSMS. She was a Co-coordinator for setting up SAP Business One Laboratory sponsored by AICTE with a fund of Rs. 7 lakhs under the Scheme MODROBS. She is the principal investigator for the ICSSR sponsored research project entitled "Influence of Social Media on Personality Development among the Millennials in Coimbatore, Tamilnadu with special reference to Facebook and Whatsapp" worth Rs. 10, 00,000. She is a recognized guide of Bharathiar University and guiding $3 \mathrm{PhD}$ Scholars. She is also a Doctoral Committee member for the $\mathrm{PhD}$ research scholars under Anna University. She is the editorial member of the journal International Management Research Review (IMRR) and review board member of the journal Apeejay Journal of Management and Technology. She is a Core team member for ACBSP International Accreditation Process in GRGSMS. 